to
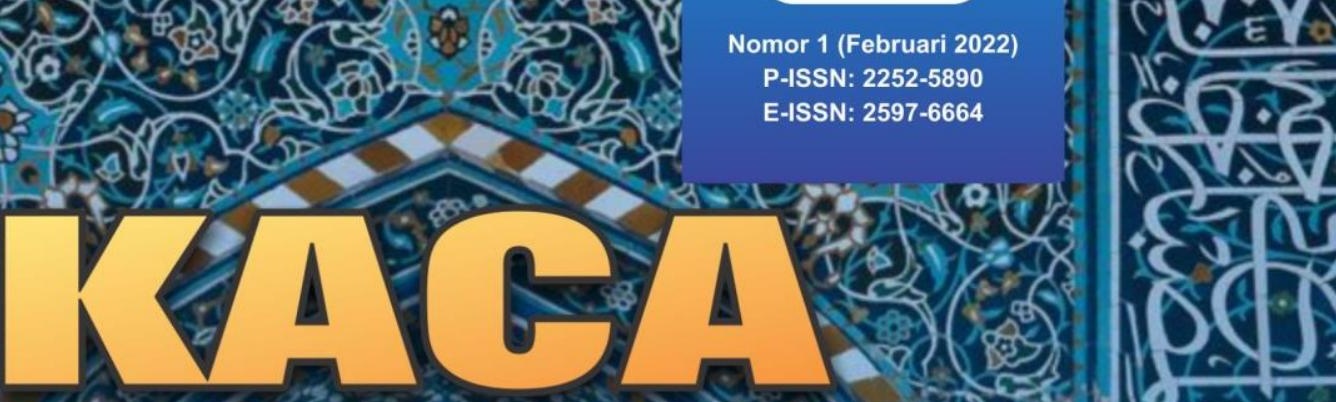

- Kritik Metafisika: Studi Komparatif Pemikiran Heidegger(1889-1976 M) dan

Suhrawardi(1154-1191 M)

Muhammad Arif

- Islam dan Media Massa: Pengarusutamaan Moderasi Islam Pada Situs Tafsiralquran.id

Abdullah Falahul Mubarok, Yoga Irama

- Melihat Tuhan dalam Perspektif Ilmu Kalam dan Tasawuf Abdul Munim Cholil

- Historisitas dan Nilai Religius Shalawat Lam Yahtalim dalam Kitab Maraqi Al-'Ubudiyah Karya Syekh Nawawi Al-Bantani Moh. Ashif Fuadi, Muhammad Aslambik

- Istifham dalam Surah Al-Qiyamah: Suatu Kajian Kebahasaan Muhamad Erpian Maulana

- Menelaah Ulang Kodifikasi Struktur Ayat dan Surah Al-Qur'an Rasm Uthmani Aspandi Aspandi, Muhammad Sarkoni
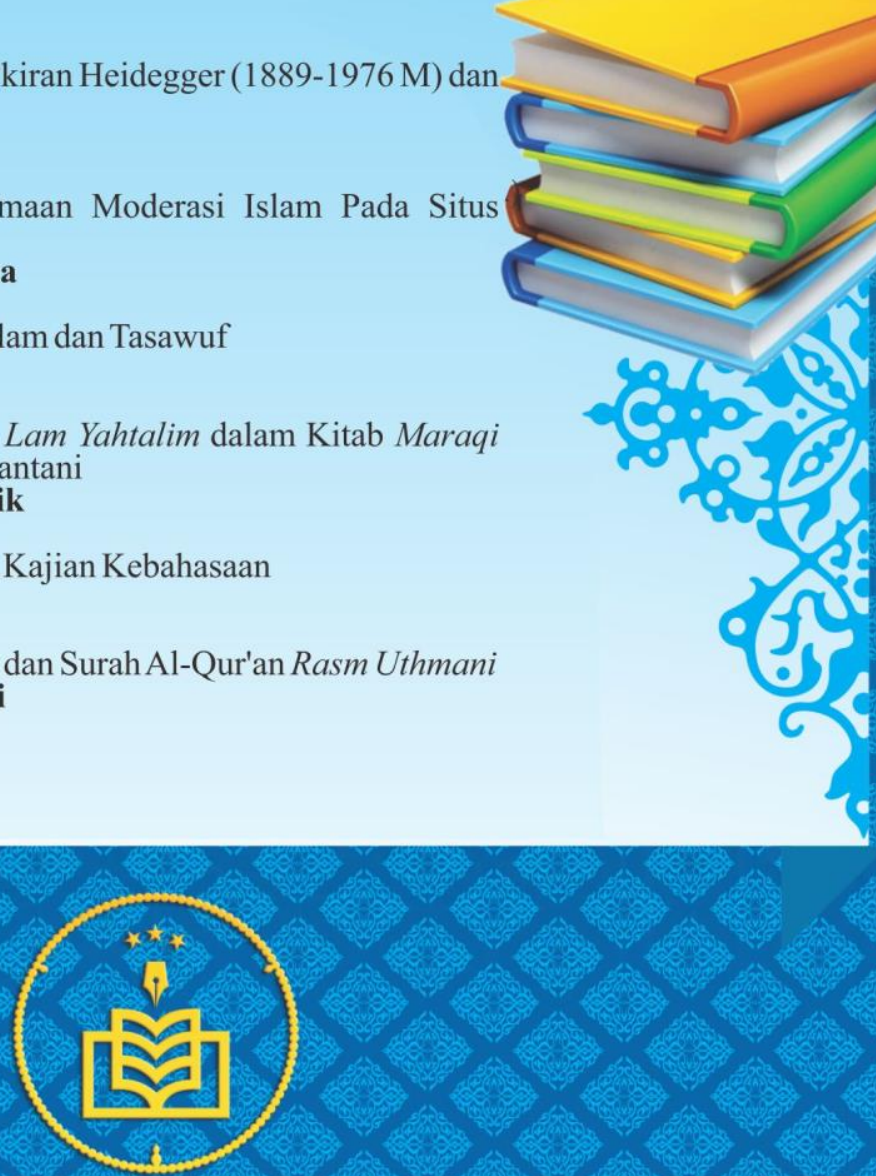

Diterbitkan oleh

SEKOLAH TINGGI AGAMA ISLAM AL FITHRAH

Jurusan Ushuluddin 


\section{KACA (Karunia Cahaya Allah): Jurnal Dialogis Ilmu Ushuluddin \\ Volume 12, Nomor 1 (Februari 2022) \\ P-ISSN: 2252-5890; E-ISSN: 2597-6664}

\section{Editor-in-Chief}

\section{EDITORIAL TEAM}

Kusroni (Sekolah Tinggi Agama Islam Al Fithrah, Surabaya)

\section{Managing Editor}

Abdulloh Hanif (Sekolah Tinggi Agama Islam Al Fithrah, Surabaya)

\section{Editorial Board}

Muhammad Kudhori, (Universitas Islam Negeri (UIN) Wali Songo, Semarang)

Mohammad Nu'man, (Universitas Islam Negeri (UIN) Sunan Ampel

Surabaya)

Iksan Kamil Sahri (Sekolah Tinggi Agama Islam Al Fithrah, Surabaya)

Mohamad Anas (Sekolah Tinggi Agama Islam Al Fithrah, Surabaya)

Achmad Imam Bashori (Sekolah Tinggi Agama Islam Al Fithrah, Surabaya)

\section{REVIEWERS}

Damanhuri (UIN Sunan Ampel Surabaya, Indonesia)

Mukhammad Zamzami (UIN Sunan Ampel Surabaya, Indonesia)

Chafid Wahyudi (Sekolah Tinggi Agama Islam Al Fithrah, Surabaya, Indonesia) Muhammad Endy Fadlullah (IAI Ibrahimy, Genteng, Banyuwangi, Indonesia)

Alvan Fathony (Universitas Nurul Jadid, Paiton, Probolinggo, Indonesia) Agus Imam Kharomen (UIN Wali Songo Semarang, Indonesia)

Khairul Muttaqin (IAIN Madura, Indonesia)

\section{ABOUT THE JOURNAL}

KACA (Karunia Cahaya Allah): Jurnal Dialogis Ilmu Ushuluddin diterbitkan oleh Jurusan Ushuluddin Sekolah Tinggi Agama Islam Al Fithrah Surabaya. Jurnal ini memuat kajian-kajian keislaman yang meliputi Tafsir, Hadis, Tasawuf, Filsafat, Pemikiran Islam, dan kajian Islam lainnya. Terbit dua kali setahun, yaitu bulan Februari-Agustus.

Saat ini, jurnal KACA telah terakreditasi SINTA peringkat 5, berdasarkan Surat Keputusan Menteri Riset dan Teknologi/Badan Riset dan Inovasi Nasional, Nomor: 200/M/KPT/2020, tanggal 23 Desember 2020, dan berlaku selama lima (5) tahun.

\section{Alamat surat menyurat:}

J1. Kedinding Lor 30 Surabaya 60129 Jawa Timur Indonesia

Email: jurnal.kaca.alfithrah@gmail.com 


\section{Daftar Isi}

Kritik Metafisika: Studi Komparatif Pemikiran Heidegger (1889-1976 M) dan Suhrawardi (1154-1191 M)

Muhammad Arif

Islam dan Media Massa: Pengarusutamaan Moderasi Islam Pada Situs Tafsiralquran.id

Abdullah Falahul Mubarok \&Yoga Irama

Melihat Tuhan dalam Perspektif Ilmu Kalam dan Tasawuf

Abdul Munim Cholil

Historisitas dan Nilai Religius Shalawat Lam Yahtalim dalam Kitab Maraqi Al-'Ubudiyah Karya Syekh Nawawi Al-Bantani

Moh. Ashif Fuadi \& Muhammad Aslambik

Istifham dalam Surah Al-Qiyamah: Suatu Kajian Kebahasaan

Muhamad Erpian Maulana

Menelaah Ulang Kodifikasi Struktur Ayat dan Surah Al-Qur'an Rasm Uthmani

Aspandi Aspandi \& Muhammad Sarkoni 
KACA (Karunia Cahaya Allah): Jurnal Dialogis Ilmu Ushuluddin

Vol. 12, No. 1 (Februari 2022) | ISSN:2252-5890; E-ISSN:2257-6664|1-25

DOI: https://doi.org/10.36781/kaca.v12i1.179

\title{
KRITIK METAFISIKA: STUDI KOMPARATIF PEMIKIRAN HEIDEGGER (1889-1976 M) DAN SUHRAWARDI (1154-1191 M)
}

\author{
Muhammad Arif \\ Universitas Islam Negeri Sunan Kalijaga Yogyakarta, Indonesia \\ Email: muhammad.arif@uin-suka.ac.id
}

\begin{abstract}
Abstrak: Heidegger dan Suhrawardi memiliki pendapat yang seirama dalam mengonsepsikan kritik metafisika. Menurut mereka Ada itu hanya dapat tersingkap melalui interaksi langsung, ontological-existential dalam bahasa Hidegger dan idlafah ishraqiyah dalam bahasa Suhrawardi. Persamaan gagasan dari dua tokoh yang berbeda zaman dan tradisi ini jelas sangat menarik untuk dikaji lebih lanjut, sehingga artikel ini mengulas tentang apa saja persamaan dan perbedaan dari dua filsuf tersebut. Artikel ini memiliki keunikan tersendiri di banding penelitian-penelitian yang ada, karena masih belum ditemukan penelitian yang mengkomparasikan pemikiran kedua filsuf tersebut. Bahkan, pada umumnya penelitian yang ada lebih menempatkan pemikiran Suhrawardi sebagai kajian tasawuf falsafi dalam dimensi logika, epistemologi, metafisika, dan bukan kritik metafisika sebagaimana menjadi tema utama artikel ini. Terakhir, artikel ini menemukan bahwa Heidegger dan Suhrawardi memiliki beberapa perbedaan dan persamaan. Perbedaan antara keduanya tampak dalam pijakan berpikir, orientasi pemikiran, dan pandangan keduanya tentang keakuan performatif, sementara dalam gagasan kritik metafisika, keduanya berada di garis yang sama.
\end{abstract}

Kata kunci: Suhrawardi, Heidegger, kritik metafisika, ontological-existential, idlafah ishraqiyah.

Abstract: Heidegger and Suhrawardi have the same page in formulating metaphysical criticism. Both of them argue that Being only could be known by direct interaction, "ontological-existential" in Heidegger's term and idlafab-Isyraqiyah in Suhrawardi's term. The similarity of ideas from two philosophers who come from different times and different cultures are interesting, then this article traces it comparatively and explains the equation and difference between both of them. This article is unique when compared to other studies, because there are still no studies which bring together Heidegger and Suhrawardi. Even, other studies generally emphasize the study of Suhrawardi in his concept of logic, epistemology, and metaphysics, not criticism of metaphysics which is the main theme of 
this article. Finally, this article found that Heidegger and Suhrawardi have similarities and differences. The difference between both of them appears in the base of their philosophy, their philosophical orientation, and their views about I-nees. On the other hand, both of them have similarities in the concept of criticism of metaphysics.

Keywords: Suhrawardi, Heidegger, metaphysical criticism, ontologicalexistential, and idlafah ishraqiyah.

\section{Pendahuluan}

Martin Heidegger dan Suhrawardi al-Maqtul merupakan dua orang filosof yang sama-sama memiliki peran besar dalam membentuk dan mengembangkan sistem filsafat, Barat dan Islam. Heidegger termasuk salah satu filosof yang banyak memberi warna pada sistem filsafat Barat kontemporer. Karya fenomenalnya, Sein und Zeit, berhasil menciptakan lompatan baru paradigma filsafat Barat. ${ }^{1}$ Di belahan dunia yang berbeda, Suhrawardi dikenal sebagai seorang filosof yang memiliki andil besar dalam meracik wacana khas filsafat Islam. Suhrawardi, meskipun perjalanan hidupnya cukup singkat, berhasil mendirikan madzhab tersendiri dalam khazanah filsafat Islam, yaitu Hikmah al-Ishraq (filsafat Iluminasi). ${ }^{2}$

Baik Heidegger maupun Suhrawardi, memiliki kemampuan istimewa berupa pikiran kritis terhadap tradisi metafisika. Heidegger dengan penuh percaya diri mengatakan bahwa era metafisika Barat tradisional adalah era kelupaan ada. ${ }^{3}$ Metafisika tradisional telah mengalami amnesia bahwa ada itu bukan adaan (entitas), sesuatu yang dapat dijelaskan dengan deskripsi. Bermula dari prasangka itulah

\footnotetext{
${ }^{1}$ Donny Gahral Adian, Martin Heidegger (Jakarta: Teraju, 2003), 11; Jeff Love and Michael Meng, "The Political Myths of Martin Heidegger," New German Critique, no. 124 (2015): 45-66.

2 Seyyed Hossein Nasr, Tiga Madz̧hab Utama Filsafat Islam, trans. Ach. Maimun Syamsuddin (Yogyakarta: IRCiSoD, 2006), 103; Mehdi Amin Razavi, Subrawardi and the School of Illumination, Curzon Sufi Series (Richmond, Surrey: Curzon Press, 1997); A. Khudori Soleh, "Filsafat Isyraqi Suhrawardi," ESENSLA: Jurnal Ilmu-Imu Ushuluddin 12, no. 1 (January 22, 2011): 1-19, https://doi.org/10.14421/esensia.v12i1.699; Fathurrahman Fathurrahman, "Filsafat Iluminasi Suhrawardi Al-Maqtul," TAJDID: Jurnal Pemikiran Keislaman Dan Kemanusiaan 2, no. 2 (October 31, 2018): 439-56, https://doi.org/10.52266/tadjid.v2i2.173.

3 Lawrence Vogel, "Hans Jonas's Diagnosis of Nihilism: The Case of Heidegger," International Journal of Philosophical Studies 3, no. 1 (March 1995): 55-72, https://doi.org/10.1080/09672559508570803; Lucas Fain, "Heidegger's Cartesian Nihilism," The Review of Metaphysics 64, no. 3 (2011): 555-79; Kris Mcdaniel, "Heidegger's Metaphysics of Material Beings," Philosophy and Phenomenological Research 87, no. 2 (2013): $332-57$.
} 
Heidegger kemudian mengusulkan proyek kritik metafisika yang pada akhirnya memunculkan relasi ontological-existential Dasein. Di lain pihak, Suhrawardi menolak dengan tegas konsep definisi/deskripsi Peripatetis. Menurut Suhrawardi definisi Peripatetis yang disusun dengan genus dan defferentia, tidaklah memadai untuk menjelaskan realitas. ${ }^{4}$ Realitas itu hanya dapat dipahami melalui idlafah isyraqiyah (hubungan iluminatif) yang pada hakikatnya sama dengan relasi ontological-existential Dasein-nya Heidegger. Kemiripan gagasan Heidegger dan Suhrawardi dalam kritik metafisika ini, tentu menarik untuk dikaji lebih jauh.

Kemenarikan dari kajian komparatif kritik metafisika Heidegger dan Suhrawardi ini juga terlatak pada kurangnya kajian kritik metafisika pada sosok Suhrawardi. Pada umumnya, istilah yang digunakan dalam menjelaskan konsep filsafat iluminasi Suhrawardi adalah ilmu Hudhuri atau pengetahuan dengan kehadiran bukan kritik metafisika. Beberapa peneliti seperti, Hussein Ziai, ${ }^{5}$ Mehdi Ha'iri Yazdi, ${ }^{6}$ John Walbridge, ${ }^{7}$ Seyyed Hossein Nasr, ${ }^{8}$ Mehdi Aminrazavi, ${ }^{9}$ Amroeni Drajat, ${ }^{10}$ Seyed N. Mousavian, ${ }^{11}$ bahkan Suhrawardi sendiripun lebih memilih menggunakan istilah ilmu Hudhuri daripada kritik metafisika. ${ }^{12}$ Konsep ilmu Hudhuri pada hakikatnya memang membahas tentang persoalan epistemologi, cara untuk memperoleh pengetahuan yang sejati, namun, menyederhanakan pemikiran Suhrawardi tersebut hanya pada wilayah epistemologi, tentu tidak cukup merepresentasikan kompleksitas konsep ilmu Hudhuri. Betul bahwa yang disampaikan itu adalah terkait dengan ilmu, tetapi ilmu dalam konteks ini adalah ilmu yang berhubungan erat dengan konsep ada.

\footnotetext{
4 Olga Louchakova-Schwartz, "A Phenomenological Approach To Illuminationist Philosophy: Suhrawardī's 'Nūr Mujarrad' And Husserl's Reduction," Philosophy East and West 65, no. 4 (2015): 1052-81; Seyed N. Mousavian, "Suhrawardi on Innateness: A Reply to John Walbridge," Philosophy East and West 64, no. 2 (2014): 486-501.

5 Hossein Ziai, Sang Pencerab Dari Timur: Subrawardi Dan Filsafat Iluminasi, trans. Muhammad Afif (Jakarta: Sadra Press, 2012).

${ }^{6}$ Mehdi Ha'iri Yazdi, Menghadirkan Cahaya Tuban: Epistemiologi Iluminasionis Dalam Filsafat Islam (Indonesia: Mizan, 2003).

7 John Walbridge, "A Response to Seyed N. Mousavian, 'Did Suhrawardi Believe in Innate Ideas as A Priori Concepts? A Note," Philosophy East and West 64, no. 2 (2014): 481-86.

${ }^{8}$ Nasr, Tiga Madæhab Utama Filsafat Islam.

9 Mehdi Aminrazavi, "How Ibn Sīnian Is Suhrawardī's Theory of Knowledge?," Philosophy East and West 53, no. 2 (2003): 203-14.

10 Amroeni Drajat, Subrawardi: kritik falsafah peripatetik (Yogyakarta: LKiS Yogyakarta, 2005).

${ }^{11}$ Mousavian, "Suhrawardi on Innateness."

12 Suhrawardi, Hikmah Al-Isyraq: Teosofi Cahaya Dan Metafisika Hudhuri, trans. Muhammad al-Fayyadl (Islamika, 2003).
}

3 KACA (Karunia Cahaya Allah): Jurnal Dialogis Ilmu Ushuluddin 
Menjadi tahu dalam ilmu Hudburi tidak lain adalah sama dengan menjadi ada. Dengan demikian, maka tentu tidak berlebihan jika dikatakan bahwa ilmu Hudhuri ini adalah bagian dari metafisika, bahkan kritik metafisika.

Selain itu, sejauh pengamatan penulis, ada tiga peneliti yang juga menempatkan konsep ilmu Hudhuri ini dalam wilayah ontologi/metafisika, yaitu Muhammad al-Fayyadl, Muhammad Taqi Misbah Yazdi dan M. Said Marsaoly. Muhammad al-Fayyadl merupakan peneliti yang secara terangterangan mengganti kata ilmu Hudhuri menjadi metafisika Hudhuri dalam menerjemahkan buku Hikmah Al-Ishraq karya Suhrawardi. Ia menambahkan anak judul terjemahan tersebut dengan teosofi cahaya dan metafisika Hudhuri, tetapi ia tidak menjelaskan tentang alasannya mengubah termininologi ilmu menjadi metafisika.

Muhammad Taqi Misbah Yazdi dalam karyanya yang berjudul Buku Daras Filsafat Islam juga lebih condong menempatkan konsep ilmu Hudhuri di wilayah ontologi daripada epistemologi. Menurutnya pengetahuan dengan kehadiran merupakan kesadaran yang bersifat intuitif, sederhana, dan langsung tentang jiwa (atau ruh) kita sendiri. Pengetahuan dan kesadaran ini merupakan keadaan esensial jiwa. Jelas topik ini terkait dengan ontologi dan psikologi filosofis yang tidak relevan dengan pembahasan epistemologi. ${ }^{13}$ Pendapat Misbah Yazdi juga diikuti oleh M. Said Marsaoly dalam artikelnya yang berjudul Mulla Shadra dan Ilmu Hudhuri. Said Marsaoly memang masih menggunakan judul ilmu Hudhuri, tetapi isi artikel yang dia tulis sepenuhnya sepakat dengan Misbah Yazdi. Ia banyak mengutip pendapat Misbah Yazdi dalam upayanya menyetarakan ilmu Hudhuri dengan konsep wujud (baca: ontologi). ${ }^{14}$

Namun, walaupun ketiganya sudah menempatkan ilmu Hudhuri sebagai sebagai metafisika, tetapi ketiganya masih belum menempatkan ilmu Hudhuri sebagai kritik metafisika. Selain itu, ketiganya juga tidak secara lebih jauh mengomparasikan pemikiran Suhrawardi ini dengan kritik metafisika Heidegger. Berpijak pada hal itu, maka artikel ini bergerak untuk mengisi kekosongan itu dengan mengkaji secara komparatif gagasan kritik metafisika Suhrawardi dan Heidegger. Kajian komparatif ini dilakukan dengan mengklasifikasikan dan mendeskripsikan hal-hal yang mengadung perbedaan dan persamaan antara kritik metafisika kedua tokoh tersebut.

${ }_{13}$ Muhammad Taqi Misbah Yazdi, Buku Daras Filsafat Islam, trans. Musa Kazhim and Saleh Bagir, 2003, 93-94.

14 M. Said Marsaoly, "Mulla Shadra dan Ilmu Hudhuri," Jurnal Mulla Shadra 1, no. 1 (2010). 


\section{Unsur-unsur Berbeda antara Heidegger dan Suhrawardi}

Unsur-unsur berbeda antara pemikiran Heidegger dan Suhrawardi ini penting untuk dijelaskan terlebih dahulu sebelum masuk pada dimensi kesamaanya. Ini penting dilakukan untuk menghindar dari asumsi-asumsi yang problematis. Asumsi-asumsi seperti menjadikan pemikiran Heidegger sebuah mistisisme (seperti dilakukan para pembaca Heidegger yang berharap menemukan suatu teori "mistisisme" dalam filsafatnya) atau menjadikan pemikiran Surhawardi sejenis filsafat eksistensialis (karena itu akan mencampuradukkan posisi Suhrawardi dengan Mulla Sadra, misalnya; kita tahu banyak peneliti terlanjur memahami Suhrawardi sebagai filsuf esensialis yang bertolak dari primasi esensi atas eksistensi). Oleh karena itu, adalah sebuah keharusan untuk mengelaborasi secara rigid dan detail perbedaan-perbedaan antara keduanya, sebelum menarik kesamaannya.

Martin Heidegger dan Suhrawardi hidup pada masa dan wilayah yang berbeda. Heidegger hidup di Jerman pada abad ke-20, sementara Suhrawardi di Alempo pada abad ke-12. Tradisi pemikiran filosofis yang berkembang pada masa hidup kedua filosof tersebut tentu juga berbeda. Heidegger memasuki rimba filsafat Barat ketika tradisi filsafat Barat sedang gencar menyanksikan keabsahan sistem positivisme dan modernitas. Suhrawardi menjejakkan diri dalam belantara filsafat Islam ketika tradisi filsafat Peripatetik sedang mendominasi wacana filsafat Islam.

Perbedaan latar historis, geografis, dan tradisi filsafat Heidegger dan Suhrawardi tersebut secara berturut-turut membuat motif-motif mereka dalam mendekati filsafat akan tampak berbeda. Perbedaan menonjol di antara mereka antara lain sebagai berikut:

\section{Perbedaan Pijakan Pemikiran}

Perbedaan yang pertama antara Heidegger dan Suhrawardi adalah terletak pada perbedaan pijakan mereka dalam membangun tradisi filsafatnya. Heidegger membangun tradisi filsafatnya melalui fenomenologi, sementara Suhrawardi melalui filsafat peripatetik, tradisi persia kuno, dan tasawwuf. Tradisi filsafat pada masa hidup Heidegger yang menjadi tren di perguruan-perguruan tinggi di Jerman adalah fenomenologi. Pemikiran Heidegger memang telah melampaui fenomenologi dan telah mencapai suatu pendirian sendiri. Tetapi dalam periode pertama karirnya, fenomenologi telah memegang peranan penting, 
bahkan Heidegger memasuki posisi filosofis yang definitif justru melalui fenomenologi. ${ }^{15}$

Fenomenologi yang dipahami di sini adalah pendekatan filosofis yang mendasarkan diri pada penyelidikan asumsi-asumsi untuk sampai kepada esensi suatu fenomena dari sudut pandang orang pertama. ${ }^{16}$ Penyelidikan tersebut bertujuan untuk mengungkapkan inti mendasar dari suatu fenomena (ide atau pengalaman), agar fenomena tersebut tampak benar-benar dalam realitasnya yang sebenarnya tanpa prasangka objektif dan subjektif. Tujuan dari fenomenologi tidak lain adalah tercapainya kesadaran murni tentang suatu hal kepada subjek yang mengamati dan mendekati. ${ }^{17}$

Fenomenologi dalam pengertian rigorus secara ekspisit, pertama kali diproklamasikan oleh Edmund Husserl, salah satu guru Heidegger. Ketika Husserl menggunakan istilah fenomenologi tersebut pada abad ke20, ia memberikan arti dan signifikansi baru "yang berbeda" dengan filosof-filosof sebelumnya. Bagi Husserl, fenomenologi adalah ilmu pengetahuan tentang fenomena, tentang objek-objek sebagaimana objekobjek itu dialami atau menghadirkan diri dalam kesadaran kita. ${ }^{18}$ Semboyan Husserl, yang dewasa ini menjadi terkenal, "Zuruck zu den Sachen selbst" (kembali kepada objek-objek itu sendiri). ${ }^{19}$

Dalam fenomenologinya, Husserl menyarankan penyelidikan Lebenswelt (dunia kehidupan sehari-hari/dunia yang dihayati). Lebenswelt adalah dunia yang disadari pra-ilmiah, prafilosofis, dan prareflektif, yaitu suatu dunia nontematis. Dunia seperti itu dewasa ini telah lenyap di balik timbunan penafsiran-penafsiran ilmiah dan filosofis. ${ }^{20}$ Untuk menemukan kembali dunia yang hilang tersebut, Husserl secara normatif mengajak setiap pengamat bersikap seolah seorang pemula. ${ }^{21}$ Ia harus membebaskan diri dari praduga-praduga atau pengandaian-pengandaian. Untuk dapat mengeksplorasi Lebenswelt pengamat harus menunda atau meletakkan dalam tanda kurung segala bentuk teori, kenyakinan, atau corak berfikir

\footnotetext{
${ }^{15}$ K. Bertens, Fenomenologi Ekessistensial (Jakarta: Penerbit Universitas Atma Jaya, 2006), v.

16 Edmund Husserl, Ideas: General Introduction to Pure Phenomenology, Routledge Classics (London; New York: Routledge, 2012).

${ }_{17}$ Muhammad Al-Fayyadl, Teologi negatif Ibn 'Arabi: kritik metafisika ketubanan (Yogyakarta, Indonesia: LKiS Yogyakarta, 2012), 17.

18 Misiak Henryk and Virginia Staudt Sexton, Psikologi fenomenologi, eksistensial dan humanistik: suatu survei historis (Bandung: Refika Aditama, 2005), 3.

${ }^{19}$ F. Budi Hardiman, Filsafat fragmentaris: deskripsi, kritik, dan dekonstruksi (Yogyakarta: Penerbit Kanisius, 2007), 39.

${ }^{20}$ Hardiman, 39.

${ }^{21}$ Donny Gahral Adian, Pengantar fenomenologi, Cet. 1 (Depok: Penerbit Koekosan, 2010), 26.
} 
yang telah masyhur. Penundaan tersebut dikenal dengan metode epoche, sebuah metode khas fenomenologi Husserl.

Selain epohe, dalam proyek fenomenologi Husserl juga dikenalkan konsep intensionalitas kesadaran. Husserl percaya bahwa setiap tindakan kesadaran pasti selalu tentang sesuatu. Husserl tidak mempersoalkan status realitas dari objek yang disadari. Bagi Husserl ada atau tidaknya objek yang dituju kesadaran itu bukanlah suatu masalah. Di sinilah sesuatu yang khas dari Husserl muncul, yaitu kritik bahwa imanensi objek tidak bisa dipertahankan. ${ }^{22}$

Proyek fenomenologi Husserl itulah yang mengantarkan Heidegger menempa sistem filsafatnya. Secara terang-terangan, Heidegger mengakui bahwa ada pengaruh kental dari Husserl dalam filsafatnya, meskipun ia sendiri mengkritik nuansa idealisme yang melingkupi fenomenologi Husserl. ${ }^{23}$ Kontribusi fenomenologi Husserl terhadap filsafat Heidegger adalah konsep lebenswelt. ${ }^{24}$ Menurut Maurice MerleauPonty, seluruh isi buku Sein un Zeit sejatinya berasal dari suatu petunjuk yang diberikan oleh Husserl sendiri, yaitu membeberkan naturlichen Weltbegriff atau Lebenswelt. ${ }^{25}$ Dengan demikian, menjadi jelas bahwa fenomenologi merupakan titik pijak Heidegger dalam menyusun proyek filsafatnya.

Berbeda dengan Heidegger yang dipengaruhi oleh fenomenologi, filsafat Suhrawardi, dipengaruhi oleh tiga tradisi besar yang menjadi sumber pemikirannya, yaitu filsafat peripatetik, tradisi Persia, dan tasawwuf. Tradisi pertama dan utama yang merangsang Suhrawardi untuk merancang pemikiran genuine-nya adalah filsafat peripatetik. Sejalan dengan proses pemikiran Suhrawardi menuju puncak kematangannya, ia pada mulanya menulis karya-karyanya yang masih bercorak peripatetis. $^{26}$ Uraian-uraian Suhrawardi tersebut, sengaja dilakukan untuk mengawali langkah berikutnya, yaitu mengkritisi keabsahan epitemologis tradisi peripatetik, khususnya teori definisi Ibnu Sina. Memang corak dalam karya-karya awalnya, seperti at-Talwihat, dan al-Masyari' wa al-Mutaharahat (masing-masing di bab II), Suhrawardi masih menggunakan pendekatakan

\footnotetext{
22 Adian, 32.

23 lihat halaman persembahan buku Martin Heidegger and Joan Stambaugh, Being and Time: A Translation of Sein Und Zeit, SUNY Series in Contemporary Continental Philosophy (Albany, NY: State University of New York Press, 1996).

${ }^{24}$ Donny Gahral Adian, Senjakala Metafisika Barat: Dari Hume Hingga Heidegger (Jakarta: Penerbit Koekoesan, 2012), 70.

${ }^{25}$ Bertens, Fenomenologi Ekssistensial, 27.

26 Drajat, Subrawardi, 133; Louchakova-Schwartz, "A PHENOMENOLOGICAL APPROACH TO ILLUMINATIONIST PHILOSOPHY.”
}

7 KACA (Karunia Cahaya Allah): Jurnal Dialogis Ilmu Ushuluddin 
Peripatetik. ${ }^{27}$ Karya-karya peripatetis tersebut memang sengaja didesain sebagai pijakan untuk memahami karya utamanya, Hikmah al-Ishraq. Kenyataan ini menguatkan kerangka piramida pemikiran Suhrawardi dengan Hikmah al-Ishraq sebagai puncaknya, ibarat sebuah perjalanan mendaki, Hikmah al-Ishraq merupakan pendakian tertinggi dan terakhirnya. ${ }^{28}$ Suhrawardi dengan sengaja membangun karya awalnya dengan corak Peripatetik untuk kemudian dia kritik dan dijadikan langkah awalnya membangun pendekatan filosofisnya, yaitu filsafat iluminasi.

Selain filsafat Peripatetik, tradisi pemikiran yang juga memiliki andil dalam penyusunan filsafat iluminasi adalah hikmah Persia kuno, yaitu Zoroaster. Zoroaster merupakan agama wahyu tertua yang masih hidup sampai sekarang. Agama ini pernah menjadi agama negara bagi kerajaan Iran (Persia) yang besar serta hidup dan berkembang hampir secara berkesinambungan sejak abad keenam sebelum Masehi sampai abad ketujuh Masehi. ${ }^{29}$ Walaupun setelah masa itu Zoroaster mengalami pasang surut, tetapi agama itu masih tetap bertahan hingga kini, setidaknya di Iran.

Ajaran-ajaran Zoroaster ini sangat menarik, secara teologis ia monoteis dan secara filosofis dualis. ${ }^{30}$ Menurut Zoroaster, hanya ada satu Tuhan sejati yang disebutnya Ahura Mazda (dalam sebutan Iran modern: Ormudz). Ahura Mazda menganjurkan kejujuran dan kebenaran. Tetapi, penganut Zoroaster juga percaya adanya roh jahat, Angra Mainyu (dalam istilah Persia modern: Ahriman) yang mencerminkan kejahatan dan kepalsuan. ${ }^{31}$ Di wilayah ontologi, dualisme Zoroaster ini membuatnya membagi seluruh jagad raya menjadi dua bagian wujud: realitas, yaitu jumlah semua ciptaan yang baik yang mengalir dari kegiatan kreatif ruh yang bajik; dan non realitas yaitu jumlah semua ciptaan yang jahat yang mengalir dari ruh yang tidak bersahabat. ${ }^{32}$ Menurut Zoroaster, dua kategori eksistensi itu merupakan dua kategori yang bertentangan. Oleh karena itu, ia kemudian menyarankan manusia untuk berada di barisan yang terang (cahaya) yang pada akhirnya akan menguasai dan menghancurkan sepenuhnya barisan yang gelap. ${ }^{33}$

27 Ziai, Sang Pencerah Dari Timur: Suhrawardi Dan Filsafat Iluminasi, 123.

28 Drajat, Subrawardi, 134.

${ }_{29}$ M. Yusron Asrofi, “Agama Zoroaster," in Agama-Agama Di Dunia (Yogyakarta: IAIN Sunan Kalijaga Press, 1988), 269.

30 Muhammad Iqbal, Metafisika Persia: Suatu Sumbangan Untuk Sejarah Filsafat Islam, trans. Joebaar Ayoeb (Bandung: Mizan, 1990), 38.

31 Michael H Hart, Ken Budha Kusumandaru, and M. Nurul Islam, 100 tokoh paling berpengarub di dunia, 2016, 449.

${ }^{32}$ Iqbal, Metafisika Persia: Suatu Sumbangan Untuk Sejarah Filsafat Islam, 40.

33 Iqbal, 40. 
Suhrawardi dalam beberapa hal bertumpu pada ajaran Zoroaster khususnya dalam penggunaan simbolisme cahaya dan kegelapan serta dalam anggelologi. ${ }^{34}$ Sebagaimana juga telah ditegaskan oleh Suhrawardi sendiri bahwa prinsip iluminasi tentang cahaya dan kegelapan yang dia usung, sejatinya juga menjadi acuan para teosof Persia kuno, seperti Jamasp, Frashaoshtra, Bozorgmehr, dan filosof-filosof lainnya sebelum mereka. Ini bukanlah prinsip yang dianut kaum kafir majusi atau pengingkaran Mani (campuran Zoroaster, Budha, dan Kristen) dan segala keyakinan yang menjurus pada penyekutuan politeistik atau penyucian Allah. ${ }^{35}$ Dengan demikian, menjadi semakin jelas bahwa prinsip dasar filsafat iluminasi juga berpijak pada tradisi Persia kuno.

Di luar tradisi filsafat peripatetik dan tradisi Persia kuno, Suhrawardi juga mempertimbangkan ajaran kebijaksanaan mistisisme Islam yang lebih dikenal dengan sebutan tasawwuf. ${ }^{36}$ Taswwuf atau Sufisme sebagaimana halnya dengan misitisisme di luar agama Islam, mempunyai tujuan memperoleh hubungan langsung dan disadari dengan Tuhan, sehingga disadari benar bahwa seseorang berada di hadiraat Tuhan. Intisari dari mistisisme, termasuk di dalamnya tasawwuf, ialah kesadaran akan adanya komunikasi dan dialog antara roh manusia dengan Tuhan melalui pengasingan diri dan kontemplasi. ${ }^{37}$ Kesadaran ini pada akhirnya akan membawa manusia dapat menjadi satu dengan Tuhan, yang dikenal dengan sebutan kesatuan kesadaran mistik.

Persoalan kesatuan mistik ini, setidaknya dapat dilihat pada dua sufi besar sebelum Suhrawardi, yaitu Abu Yazid al-Buastami (w. 874 M) dan Husain Ibn Mansur al-Hallaj (858-922 M). Abu Yazid dikenal sebagai sufi yang mengajarkan konsep ittihad. Konsep ini merupakan suatu tingkatan dalam tasawwuf yang menjelaskan bahwa seorang sufi telah merasa dirinya bersatu dengan Tuhan, karena yang dilihat dan dirasakan hanya satu wujud. ${ }^{38}$ Sedikit berbeda dengan Abu Yazid, Husain Ibn Mansur al-Hallaj juga memunculkan konsep kesadaran kesatuan mistik yang dikenal dengan bulul. Hulul merupakan faham tasawwuf yang mengatakan bahwa Tuhan memilih tubuh-tubuh manusia tertentu untuk mengambil tempat di dalamnya, setelah sifat-sifat kemanusiaan yang ada

\footnotetext{
${ }^{34}$ Nasr, Tiga Madæhab Utama Filsafat Islam, 110.

${ }^{35}$ Suhrawardi, Hikmah Al-Isyraq: Teosofi Cahaya Dan Metafisika Hudhuri, xxxiii.

36 Tasawwuf yang menjadi pokok pembahasan di sini bukan tasawmuf akblaqi Gazalian, melainkan tasawmuf wujudiyah atau tasawwuf falsafi.

${ }^{37}$ Harun Nasution, Falsafat dan mistisisme dalam Islam falsafat Islam - mistisisme Islam - tasawnf (Jakarta: Bulan Bintang, 2010), 54.

${ }^{38}$ Nasution, 84.
}

9 KACA (Karunia Cahaya Allah): Jurnal Dialogis Ilmu Ushuluddin 
dalam tubuh itu dilenyapkan. ${ }^{39}$ Prinsip-prinsip tasawwuf tersebut banyak menginspirasi Suhrawardi dalam membangun konstruksi filsafatnya. Suhrawardi bahkan mengatakan bahwa tasawwuf itu lebih utama daripada filsafat diskursif. Hal ini setidaknya dapat dilihat dalam konsepnya tentang idlafah ishraqiyyah (ontological-existential) yang begitu kental dengan nuansa tasawwuf daripada filsafat diskursif.

\section{Konsepsi Filsafat Berdimensi Kemanusiaan dan Ketuhanan}

Perbedaan kedua antara Heidegger dan Suhrawardi adalah terletak pada konsepsi filsafatnya. Konsepsi filsafat Heidegger berdimensi kemanusiaan, sementara konsepsi filsafat Suhrawardi berdimensi keilahian/religius. Titik tolak kritik metafisika Heidegger adalah Dasein. Istilah tersebut digunakan oleh Heidegger untuk menggambarkan entitas yang dapat mepertanyakan keberadaanya, yaitu manusia. Dasein mengandung pengertian bahwa manusia pada hakikatnya adalah ada (sein) yang berada di sana (da). Manusia tidak ada begitu saja, melainkan senantiasa secara erat berkaitan dengan "adanya" sendiri. Berbeda dengan benda-benda serta bintang-bintang, manusia senantiasa terlibat dalam "adanya". 40

Heidegger lebih memilih istilah Dasein dalam menggambarkan manusia daripada istilah yang lain seperti buman being, aku, kesadaran, dan lain-lain. Hal ini tidak lain karena dalam pandangan Heidegger, di antara istilah-istilah tersebut, Dasein-lah yang lebih bisa mewakili ada pada dimensi ontologis (ready-to-hand) dan bukan ontis (present-at-hand). Ada Dasein sudah melampaui relasi yang bersifat teoritis, dan telah mencapai relasi ontological-existential. ${ }^{41}$ Sementara istilah kesadaran yang lain masih belum bisa melepaskan diri dari relasi ontis.

Penjelasan tentang dimensi ontologis Dasein ini kemudian oleh Heidegger dilengkapi dengan pernyataan bahwa Dasein selalu sudah ditemukan dalam dunia. ${ }^{42}$ Menurut Heidegger, ciri utama dari Dasein itu berada-di-dalam-dunia (Being-in-the-world). Dari awal keberadaannya Dasein itu sudah berinteraksi dengan dunia, tanpa sekalipun berada tersendiri lepas dari dunia. ${ }^{43}$ Akan tetapi, perlu diperjelas di sini bahwa dunia yang dimaksud Heidegger dalam konsep ini bukanlah bumi. Dunia itu adalahdari sudut pandang Dasein-suatu tempat untuk ditinggali. Dunia

\footnotetext{
${ }^{39}$ Nasution, 88.

${ }^{40}$ Kaelan, Filsafat bahasa: masalah dan perkembangannya (Yogyakarta, Indonesia: Paradigma

Yogyakarta, 2002), 195.

${ }^{41}$ lihat Heidegger and Stambaugh, Being and Time, 13-17.

${ }^{42}$ Heidegger and Stambaugh, 47.

${ }^{43}$ Anton Bakker, Antropologi Metafisike (Yogyakarta: Kanisius, 2000), 23.
} 
ontological-existential dasein dengan demikian, adalah dunia yang ditinggali oleh Dasein dan dunia itu tidak ditinggali begitu saja, tetapi mempengaruhi dan dipengaruhi oleh Dasein. ${ }^{44}$

Berikutnya, interaksi antara Dasein dengan dunianya tersebut membawa Dasein memiliki tiga karakter yang dominan. Ketiga karakter itu adalah faktisitas, pemahaman, dan kejatuhan, ${ }^{45}$ yang oleh Heidegger lalu diformulasikan sebagai satu karakter yang ia sebut; being-ahead-of-itself-inalready-being-in-a-world. ${ }^{46}$ Kata bersambung yang pajang tersebut diperas kembali hingga menjadi satu kata yang disebut dengan furcorge (care/keprihatinan). Namun, perlu digarisbawahi bahwa keprihatinan yang dimaksud Heidegger ini bukanlah sebuah aktivitas psikologis. Keprihatinan Dasein ini adalah struktur ontologis atau cara berada Dasein. $^{47}$

Formulasi Heidegger tentang keprihatinan ini secara berturut-turut menuntun konsepsi filsafatnya untuk berorientasi pada kemanusiaan. Keprihatinan Heidegger tersebut secara gamblang menyiratkan keprihatinan akan struktur ontologis manusia. Menjadi lumrah kemudian jika sistem filsafat Heidegger banyak menjadi inspirasi bagi filosof eksistensialis kondang seperti Sartre dan filosof Hermeneutik seperti Hans George Gadamer. ${ }^{48}$

Berikutnya, jika konsepsi filsafat Heidegger memusatkan perhatiannya pada manusia (dasein), maka Suhrawardi berorientasi pada dimensi keilahian. Berbeda dengan Heidegger, titik tolak pemikiran filosofis Suhrawardi sarat akan nuansa kecintaan yang kuat terhadap sang ilahi. Kecenderungan dimensi keilahian ini tidak lain adalah akibat pengaruh tasawwuf/mistisisme yang melingkupi filsafat Suhrawardi.

Konsepsi Suhrawardi tentang ilmu hudhuri tidak dapat dielakkan merupakan bagian dari mistisisme Islam yang bercorak filosofis. Sebagaimana mistisisme, ilmu budburi juga mencita-citakan terjadinya kesatuan kesadaran mistik antara insan dan ilahi. Melalui ilmu budburi Suhrawardi mencoba untuk mendedah problem utama kesadaran kesatuan mistik, yaitu bagaimana dua realitas yang berbeda, manusia dan Tuhan, menjadi satu dan sama dalam proses pengalaman mistik. Menjawab

\footnotetext{
44 Heidegger and Stambaugh, Being and Time, 50.

45 Adian, Senjakala Metafisika Barat: Dari Hume Hingga Heidegger, 81.

${ }^{46}$ Heidegger and Stambaugh, Being and Time, 179.

${ }^{47}$ Heidegger and Stambaugh, 181.

48 Eric Lemay, J. Glenn Pitts, and Paul Gordon, Heidegger untuk pemula (Yogyakarta: Kanisius, 2001), 102.
}

11 KACA (Karunia Cahaya Allah): Jurnal Dialogis Ilmu Ushuluddin 
problem tersebut, Suhrawardi kemudian memunculkan konsep idhafah ishraqiyah (relasi iluminatif) ${ }^{49}$ sebagai ciri intrinsik ilmu hudburi.

Konsekuensi logis dari konsep tersebut adalah bahwa mistisisme hanya bisa dirumuskan dalam bahasa "ontological-existential" sebagai karakter inti dari epistemologi ilmu budhuri. ${ }^{50}$ Inilah nilai lebih mistisisme Suhrawardi daripada para pendahulunya seperti al-Hallaj dan Abu Yazid al-Bustomi. Selain menjadikan pemikirannya berdimensi mistik, Suhrawardi juga membuat pemikirannya menjadi sebuah keniscayaan filsafat. Keniscayaan ini tidak lain karena dalam persepektif ilmu hudhuri, pengalaman-pengalaman mistik dicirikan oleh kualitas noetic. ${ }^{51}$ Gambaran tentang konsep ilmu budhuri di atas teramat cukup kiranya untuk menempatkan konsep filsafat Suhrawardi adalah berdimensi keilahian.

\section{Keakuan Performatif Sebagai Ontis dan Keakuan Performatif Sebagai Ontologis}

Perbedaan terakhir antara Heidegger dan Suhrawardi adalah perbedaan perspektif mereka dalam menilai kesadaran diri atau kekuan performatif. Heidegger mengkategorikan keakuan performatif sebagai bagian dari level kesadaran ontis (deskriptif/teoritis) dan bukan ontologis (ontological-existential), sementara Suhrawardi melihat keakuan performatif sebagai kesadaran ontologis. Perbedaan perspektif ini merupakan perbedaan terpenting dan harus diketahui sebelum melangkah lebih jauh pada sisi-sisi persamaan antara kedua filosof tersebut. Ini tidak lain karena persamaan konsepsi Heidegger dan Suhrawardi sepenuhnya bersandar pada perbedaan yang terakhir ini.

Persoalan tentang kesadaran diri atau keakuan performatif merupakan tema yang sudah berkembang sejak mula filsafat menampakkan dirinya sebagai bagian dari konsepsi keilmuan. Sejak masa Socrates tema kesadaran diri atau keakuan performatif telah menjadi pembahasan utama dalam studi filsafat. Hanya saja, ketika Heidegger muncul dalam kancah studi filsafat kontemporer, tema keakuan performatif kemudian dipertanyakan keabsahannya. Ini juga yang

\footnotetext{
${ }^{49}$ Konsep ini secara terperinci akan diulas pada bab berikutnya.

50 Muhammad Sabri, Lonceng Kematian Mistisme Agama (Yogyakarta: Resist Book, 2009), 273.

51 Noetic adalah bentuk ajektif dari term noesis, yaitu suatu tindakan kesadaran yang langsung terarah kepada realitas atau objek-objek. Tindakan mengalami objek-objek itu merupakan suatu bentuk pengetahuan yang berbeda dari pengetahuan metodis-ilmiah karena mensyaratkan berkorelasinya subjek dan objek; bahwa tidak ada subjek tanpa objek dan tidak ada objek tanpa subjek; bahwa kesadaran mengonstitusi realitas dan realitas menampakkan diri pada kesadaran. Di sini subjek dan objek diposisikan secara serentak dan identik. Lihat Yazdi, Menghadirkan Cabaya Tuban, 37.
} 
membuat Heidegger lebih memilih menggunakan terminologi Dasein dari pada buman being, subjek, aku, pesona, kesadaran, atau keakuan performatif. $^{52}$

Menurut Heidegger, keakuan performatif sebagaimana dipahami oleh filosof-filosof sebelum Heidegger masih belum menyentuh pada kesadaran ontologis. Mengapa demikian? Heidegger mengawali kritiknya tersebut dengan mengutip ungkapan St. Agustinus "Quid autem propinquius meipsomibi?" ("Masih adalah sesuatu yang lebih tampak bagiku selain diriku sendiri?”). Menurut Heidegger, ungkapan itu benar hanya pada sisi ontis dan belum sampai pada sisi ontologis Dasein. Untuk sampai pada kesadaran yang lebih tinggi, yaitu ontologis, ia telah gagal untuk memperlihatkan adanya dalam fenomena yang lebih dekat. ${ }^{53}$ Ini tidak lain karena, menurut Heidegger pengenalan diri yang semacam itu, telah menciptakan distansi antara kesadaran dan diri.

Pernyataan tersebut di atas berkaitan erat dengan relasi Dasein dan Ada. Terinspirasi dari Plato, Heidegger berargumentasi bahwa suatu pertanyaan selalu dibimbing oleh suatu pengetahuan yang kabur tentang apa yang ditanyakan. ${ }^{54}$ Dasein merupakan satu-satunya entitas yang mempunyai pengetahuan kabur tentang Ada, sehingga hanya Dasein-lah yang mampu mempertanyakan keberadaannya. Berdasarkan hal itu, dapat diketahui bahwa Heidegger memahami relasi Dasein dan Ada itu tidak terbangun secara eksternal, tapi sudah ada secara internal. Dengan kata lain, Dasein merupakan titik tolak penyingkapan ada (alethea).

Namun, Heidegger tidak hanya berhenti pada titik ini. Lebih jauh, meskipun Dasein merupakan tempat penyingkapan Ada, Heidegger masih mempermasalahkan apakah Dasein itu menyadarinya atau tidak. Kalau ia tidak menyadarinya dan tenggelam pada kesehariannya seperti manusia kebanyakan, maka ia masih berada pada dimensi ontis. ${ }^{55}$ Sebaliknya, kalau ia menyadari keberadaannya lalu memepertanyakannya, maka ia sudah berada pada level ontologis. Dengan kata lain, seberapa tampak Ada dalam kesadaran diri tersebut sangat menentukan dimensi ontis dan ontologis Dasein. Itulah kemudian mengapa Heidegger berpendapat bahwa, apa yang secara ontis paling dekat dan terasa familiar, adalah yang secara ontologis terjauh. Dengan demikian, yang ontis mengasingkan yang ontologis, karena yang ontis membuat Dasein lupa pada yang ontologis.

52 Muhammad Arif, "HERMENEUTIKA HEIDEGGER DAN RELEVANSINYA TERHADAP KAJIAN AL-QUR'AN," Jurnal Studi Ilmu-Imu Al-Qur'an Dan Hadis 16, no.

1 (March 16, 2015): 85-106, https://doi.org/10.14421/qh.2015.1601-05.

${ }^{53}$ Heidegger and Stambaugh, Being and Time, 9.

${ }^{54}$ Adian, Senjakala Metafisika Barat: Dari Hume Hingga Heidegger, 73.

${ }^{55}$ Heidegger and Stambaugh, Being and Time, 11.

13 KACA (Karunia Cahaya Allah): Jurnal Dialogis Ilmu Ushuluddin 
Pendapat Heidegger tentang pengenalan diri tersebut agaknya kurang bijaksana jika disandingkan dengan konsep keakuan performatif Suhrawardi. Pengenalan diri atau keakuan performatif menurut Suhrawardi tidak menjadikan manusia terasing dari kesadaran ontologisnya. Tidak ada distansi antara diri dan keakuan performatif dalam proses kesadaran tersebut. Keakuan performatif, merupakan subjek aku yang asali, primer, dan langsung yang aktif dan hadir dalam setiap tindakan, termasuk tindakan mengetahui. Ia bukan aku yang direnungkan, dikonsepsi, direpresentasikan, dan bukan aku yang ditindak, dihadirkan, ditujuk. Ia benar-benar subjek telanjang yang hadir dan imanen dalam seluruh tindakan fenomenal, dan ia merupakan subjek aktif yang berfikir, berbicara, dan bertindak. ${ }^{56}$ Dengan perkataan lain, setiap subjek yang mengetahui, yakni aku dalam dirinya sendiri, adalah suatu pengetahuan swaobjek yang lengkap dan kemudian memunculkan pertanyaan mengenai hakikat pengetahuan yang hadir dalam dirinya.

Berdasarkan pengertian keakuan performatif yang dibagun Suhrawardi tersebut, tidak berlebihan kiranya jika kita mengafirmasi bahwa konsep keakuan performatif Suhrawardi adalah berada pada level ontologis. Walaupun Suhrawardi tidak secara langsung mengatakan konsepnya tersebut masuk dalam dimensi ontologis, tetapi secara subtantif ia tetap tergolong kesadaran ontologis. Tidak seperti kesadaran diri yang dibangun oleh filosof lain, seperti yang disebut Heidegger, dalam keakuan performatif Suhrawardi, subjek aku tidak hanyut dalam denyut kesibukan sehari-hari, melainkan aktif menyadari keberadaanya dan menjadi modus keberadaannya atau eksistensinya.

Lebih lajut, Suhrawardi juga membedakan tingkat keakuan performatif menjadi "keakuan" (anaiyah) dan "kediaan" (buwaiyab). Term kediaan yang dimaksud di sini bukan mengacu kepada dunia eksternal, melainkan kesadaran akan objek atau segala sesuatu di luar kehadiran subjek yang langsung. Jadi, aku yang diketahui lewat representasi itu adalah suatu kediaan, karena diperlakukan sebagai objek ${ }^{57}$ dan masih bersifat pengetahuan, bukan modus keberadaan. Diktum keakuan dan kediaan Suhrawardi ini merepresentasikan bahwa Suhrawardi juga menyadari akan perbedaan kesadaran ontis dan ontologis. Suhrawardi juga meyakini bahwa yang ontologis (keakuan) adalah lebih primordial daripada yang ontis (kediaan). Dengan demikian, menjadi tidak rasional kemudian jika dikatakan keakuan performatif Suhrawardi terjatuh pada wilayah ontis dan bukan ontologis.

\footnotetext{
${ }^{56}$ Yazdi, Menghadirkan Cahaya Tuhan, 33.

${ }^{57}$ Yazdi, 150.
} 


\section{Sisi Persamaan Konsepsi Filsafat Heidegger dan Suhrawardi}

Di atas telah dijelaskan tentang tiga prinsip yang berbeda antara filsafat Heidegger dan Suhrawardi. Terdapat ide-ide dasar dan perspektif yang secara fundamental tidak berada di garis yang sama antara Heidegger dan Suhrawardi. Akan tetapi walaupun demikian, ini bukan lantas menunjukkan tidak ada persamaan di antara keduanya. Betapapun dalam beberapa hal mendasar mereka cenderung berseberangan, tetapi di selasela peliknya konsepsi filsafat Heidegger dan Suhrawardi, ternyata tersimpan motif-motif yang dapat dipertemukan. Sejauh pengamatan penulis, baik Heidegger maupun Suhrawardi memiliki irama yang sama dalam mengkonsepsikan Ada dan cara Ada menyingkapkan diri. Bagaimana persamaan itu menjadi mungkin?

\section{Kritik Metafisika: antara ontological-existential dan idlafah ishraqiyyah}

Keseluruhan filsafat Heidegger merupakan studi tentang Ada. Langkah Heidegger dalam dunia filsafat diawali dengan kritiknya atas tradisi metafisika. Heidegger mengklaim tradisi metafisika Barat telah melupakan Ada (suatu pernyataan yang sangat berani dan sampai saat ini menjadi objek kontroversi). Oleh tradisi metafisika Barat, Ada telah dikaburkan sehingga hanya menampakkan adaan/entitas dan bukan Ada. Hal ini terjadi karena metafisika tidak mampu melihat perbedaan ontologis antara Ada dan entitas. Ketidakmampuan metafisika melihat perbedaan ontologis tersebut telah berlangsung sejak Plato, saat itu perbedaan ontologis telah dilupakan dan diubah ke dalam hirarki "ada yang tampak" (sensible being) dan "ada yang tak tampak" (supersensible being) dengan melihat yang terakhir lebih rendah tingkatnya dari yang kedua. ${ }^{58}$ Realitas kelupaan Ada itu pada gilirannya memantik Heidegger untuk membuat pemikiran filsafatnya sebagai sebuah proyek mengentaskan persoalan kelupaan Ada (kritik metafisika).

Proyek pengentasan kelupaan Ada Heidegger tersebut dibuka dengan upaya meninjau ulang pertanyaan paling mendasar dalam metafisika, yakni pertanyaan soal Ada. ${ }^{59}$ Pertanyaan, "Apa itu ada?” yang selama ini menjadi fondasi utama pertanyaan metafisika, harus diganti menjadi pertanyaan “Apa itu makna ber-ada?”. Pertanyaan metafisika baru usulan Heidegger tersebut memiliki perbedaan signifikan dengan pertanyaan metafisika sebelumnya yang hanya berada di tataran ontis,

58 Yasraf Amir Piliang, Post-Realitas: Realitas Kebudayaan dalam Era Post-Metafisika (Yogyakarta: Jalasutra, 2018), 316; Emma R. Jones, “The Future of Sexuate Difference: Irigaray, Heidegger, Ontology, and Ethics,” L'Esprit Créateur 52, no. 3 (2012): 26-39.

${ }^{59}$ Heidegger and Stambaugh, Being and Time, 1.

15 KACA (Karunia Cahaya Allah): Jurnal Dialogis Ilmu Ushuluddin 
karena pertanyaan baru tersebut mengarah kepada pertanyaan ontologis. Jika pertanyaan metafisika biasanya hanya bertanya sambil lalu tentang sesuatu (ontis), maka pertanyaan baru usulan Heidegger terssebut bertanya dengan orientasi kejernihan atas status ontologis sesuatu (ontologis). ${ }^{60}$

Lebih lanjut, Heidegger menegaskan bahwa Ada bukan ada entitas (adaan) melainkan apa yang membedakan antara ada entitas dan nonentitas. Ada menurut Heidegger sebenarnya tidak lain adalah keseluruhan entitas dalam jaringan. Jadi, bertanya tentang ada harus dibedakan dengan bertanya tentang entitas. Apabila pertanyaan tentang entitas dapat dijawab dengan suatu deskripsi (misalnya pertanyaan tentang apa itu mesin tik, dapat dijawab dengan alat untuk menulis dengan memakai pita), maka pertanyaan tentang ada merupakan pertanyaan tentang apa makna ber-ada sebagai entitas (implisit: membedakannya dari non entitas). ${ }^{61}$ Dengan demikian, dapat disimpulkan bahwa Heidegger memiliki perspektif berbeda dalam memandang Ada dan entitas, di mana Ada tidak dapat dijelaskan dengan deskripisi dan sebaliknya entitas dapat dijelaskan dengan deskripsi.

Motif-motif pengentasan masalah kelupaan Ada Heidegger tersebut, ternyata juga dianut oleh Suhrawardi. Keseluruhan filsafat Suhrawardi tidak lain adalah kritik terhadap filsafat Peripatetik, khususnya dalam teori definisi. Suhrawardi dengan penuh percaya diri, meragukan keabsahan teori definisi sebagai salah satu cara untuk memperoleh pengetahuan. Suhrawardi menganggap bahwa teori peripatetis tersebut gagal membangun teori pengetahuan yang mapan, yang dapat mendatangkan pengetahuan yang sebenarnya. ${ }^{62}$

Ada tiga alasan mendasar mengapa Suhrawardi melakukan kritik tajam terhadap teori definisi. Pertama, pada suatu objek yang didefinisikan untuk subjek yang tidak memahaminya, pendefinisian harus ditempuh dengan mengklasifikasi segala hal yang membuat objek itu spesifik, baik dalam satuan, parsialitas, atau kolektivitasnya. Definisi harus dibuat lebih gamblang daripada objek tersebut dan bukan setaraf, lebih samar atau bahkan tidak diketahui tanpa sesuatu yang mendifinisikannya. ${ }^{63}$ Suhrawardi tegas mengingatkan bahwa pengertian atas realitas tidak sekedar mengganti kata, karena kata-kata hanya berguna bagi orang yang mengetahui realitas karena pengertian kata itu masih cukup samar untuk dipahami. ${ }^{64}$

\footnotetext{
${ }^{60}$ Heidegger and Stambaugh, 7-9.

${ }^{61}$ Adian, Senjakala Metafisika Barat: Dari Hume Hingga Heidegger, 71.

${ }^{62}$ Razavi, Subrawardi and the School of Illumination, 52.

${ }^{63}$ Suhrawardi, Hikmah Al-Isyraq: Teosofi Cahaya Dan Metafisika Hudhuri, 7.

${ }^{64}$ Suhrawardi, 7.
} 
Kedua, menurut Suhrawardi teori definisi Peripatetik yang hanya disusun genus dan defferentia adalah tidak valid. Difenisi yang disusun dengan cara demikian hanya berusaha membedakan (tamyiz) sesuatu yang didefinisikan. Padahal definisi semestinya merupakan konsepsi tentang inti sesuatu yang dengan begitu ia akan mengikuti sesuatu yang dibedakan itu. ${ }^{65}$ Dengan kata lain, apa yang akan didefinisikan harus sudah diketahui sebelum objek yang didefinisikan. ${ }^{66}$

Ketiga, definisi harus dapat mengombinasikan semua sifat dari sesuatu yang didefinisikan. ${ }^{67}$ Ada sangat banyak sifat-sifat yang menyertai sesuatu yang akan didefinisikan, sehingga mendefiniskan sesuatu itu tidaklah memadai jika hanya menyebutkan esensi alaminya saja. ${ }^{6}$ Semua sifat-sifat yang menyertai atau melekat dalam sesuatu tersebut harus juga dimasukkan dalam definisi, bukan hanya esensinya saja. Definisi yang valid itu adalah ketika sebuah definisi menyebutkan satu demi satu seluruh sifat sesuatu yang akan didefinisikan secara kolektif, walaupun tidak menutup kemungkinan sifat-sifat yang disebutkan itu juga dimiliki oleh sesuatu yang lain. ${ }^{69}$ Suhrawardi mengatakan secara eksplisit bahwa pengetahuan tentang keseluruhan hal esensial seperti itu, melalui metode penguraian bagaimanapun juga tidak mungkin. Sebab, sesuatu yang didefinisikan boleh jadi memiliki kemajemukan sifat-sifat yang tidak tampak (ghaira zabiri). ${ }^{70}$

Berpijak pada tiga alasan tersebut, Suhrawardi kemudian mengambil sikap untuk meninggalkan teori definisi Peripatetik dan memunculkan sebuah konsepsi baru. Menurut Suhrawardi pendifinisian harus dilakukan dengan memungut faktor yang menyebabkan terjadinya hubungan suplementasi (idlafah). ${ }^{71}$ Hubungan suplementasi ini merupakan hubungan langsung antara subjek dan objek yang diketahui. Inilah yang dikatakan dengan relasi iluminatif (idlafah ishraqiyyah). ${ }^{72}$ Pada titik ini orang tidak lagi memerlukan definisi. Menurut Suhrawardi, hubungan iluminatif tersebut adalah sesuatu yang primordial dalam mencapai pengetahuan yang sesungguhnya, sementara pengetahuan deskriptif atau definitif merupakan derivasinya.

${ }^{65}$ Ziai, Sang Pencerah Dari Timur: Subrawardi Dan Filsafat Iluminasi, 146.

${ }^{66}$ Suhrawardi, Hikmah Al-Isyraq: Teosofi Cahaya Dan Metafisika Hudhuri, 8.

${ }^{67}$ Mehdi Aminrazavi and Ian Richard Netton, Signifikansi Karya Subrawardi, trans. Ribut

Wahyudi (Yogyakarta: Pustaka Sufi, 2003), 9.

${ }^{68}$ Drajat, Subrawardi, 141.

${ }^{69}$ Iqbal, Metafisika Persia: Suatu Sumbangan Untuk Sejarah Filsafat Islam, 99.

${ }^{70}$ Ziai, Sang Pencerah Dari Timur: Subrawardi Dan Filsafat Iluminasi, 170.

${ }^{71}$ Suhrawardi, Hikmah Al-Isyraq: Teosofi Cahaya Dan Metafisika Hudhuri, 9.

72 Drajat, Subrawardi, 142.

17 KACA (Karunia Cahaya Allah): Jurnal Dialogis Ilmu Ushuluddin 
Konsekuensi logis dari pengetahuan dengan relasi iluminatif ini adalah ia memiliki objek immanen. Objek ini adalah objek yang langsung (tanpa representasi) dan identik dengan eksistensi subjek yang mengetahui. Ia bersifat intrinsik dan pasti merupakan bagian dari tindakan subjek yang mengetahui. ${ }^{73}$ Dengan cara ini subjek dipaksa untuk mengidentikkan, dalam kondisi-kondisi tertentu, realitas pikiran subjek dengan realitas objektif objek karena keduanya terikat bersama dalam satu unifikasi eksistensial (hadir). Kata mengetahui karenanya tidak memainkan peran lebih dari sekedar penegasan keadaan wujud tertentu atau penyingkap status eksistensial. ${ }^{74}$

Melihat penolakan Suhrawardi akan teori definisi Peripatetik dan gagasannya tentang relasi iluminatif, sepertinya secara tidak langsung ia telah menginsafi era kelupaan Ada. Menggunakan postulat-postulat negatif, Suhrawardi berhasil meretas jalan melampaui era kelupaan Ada. Sikap Suhrawardi yang menolak pengetahuan diskriptif dan mengafirmasi pengetahuan melalui relasi iluminatif, telah menunjukkan bahwa Suhrawardi lolos dari jerat kekaburan antara Ada dan entitas. Suhrawardi telah berhasil memurnikan makna Ada dari bayang-bayang entitas. Dengan demikian, tentu tidak berlebihan jika dikatakan bahwa Suhrawardi berada pada garis yang sama dengan Heidegger dalam melihat Ada, di mana keduanya sama-sama memberikan garis tegas perbedaan antara Ada dan entitas.

Persamaan persepsi antara Heidegger dan Suhrawardi dalam memandang Ada, secara berturut-turut menuntun mereka untuk juga seirama dalam mengkonsepsikan penyingkapan Ada. Perspektif Heidegger tentang Ada membawa Heidegger menyatakan Dasein sebagai titik tolak penyingkapan Ada. Demikian halnya dengan Suhrawardi, ia mengatakan bahwa penyingkapan Ada hanya mungkin terjadi pada Cahaya. Meskipun kedua filosof tersebut tidak menggunakan terminologi yang sama, tetapi secara esensial mereka memiliki motif yang sama dalam menyingkapkan Ada. Mengapa demikian?

Menurut Heidegger, hal yang harus dilakukan untuk menyingkapkan Ada itu dimulai dari suatu entitas yang menanyakan Ada. ${ }^{75}$ Tidak semua entitas dapat mengajukan pertanyaan tentang Ada. Lemari, baju, gadget, unta, atau monyet misalnya, mereka tentu tidak bisa dan tidak akan pernah mempersoalkan keberadaannya. Entitas-entitas tersebut tidak dapat mengajukan pertanyaan tentang, karena mereka tidak memiliki

\footnotetext{
${ }^{73}$ Drajat, 88.

${ }^{74}$ Yazdi, Menghadirkean Cahaya Tuban, 126-27.

${ }^{75}$ F. Budi Hardiman, Heidegger dan Mistik Kesehatan: Roman (Jakarta: KPG, 2016), 46.
} 
pengetahuan kabur tentang Ada. Hanyalah Dasein sanggup memiliki pengetahuan kabur tentang ada dan dapat mempertanyakan keberadaannya. Dengan demikian, dapat disimpulkan bahwa Dasein adalah satu-satunya entitas khusus yang memiliki kualifikasi sebagai pangkal tolak untuk meneliti Ada. ${ }^{76}$

Selanjutnya, bagaimana modus Dasein menyingkapkan atau meneliti Ada, menurut Heidegger? Seperti sudah disampaikan sebelumnya, Heidegger senantiasa menggunakan kata Dasein bersamaan dengan kata being-in-the-world (Ada-di-dalam-dunia). Artinya, Dasein dalam kacamata Heidegger itu selalu sudah ditemukan dalam dunia. ${ }^{77}$ Dunia macam apakah itu? Sebagaimana telah dijelaskan sebelumnya dunia yang dimaksud Heidegger adalah dunia ontological-existential. Ia adalah dunia yang ditinggali Dasein yang tidak ditinggali begitu saja, melainkan turut mempengaruhi dan dipengaruhi oleh Dasein. ${ }^{78}$

Maksud dari dunia ontological-existential akan semakin jelas ketika ia dikaitkan dengan lingkungan keseharian manusia yang sangat biasa. ${ }^{79}$ Menurut Heidegger agar dunia keseharian biasa itu bisa menjadi dunia ontological-existential, ia haruslah harus dilihat sebagai subjek-subjek praktis/ready-to-hand (interaksi langsung), bukan sebagai objek-objek teoritis/present-at-hand (deskriptif berjarak). Untuk lebih mudah dipahami barangkali ini perlu dijelaskan dengan contoh sebagai berikut, dalam kehidupan sehari-hari mahasiswa sekarang ini terbiasa memakai/berinteraksi langsung dengan handphone, baik untuk kuliah daring, komunikasi, ataupun bermain game. Tiba-tiba, pada suatu hari handphone yang biasa ia pakai itu hilang dicuri seseorang. Maka, saat itu juga mahasiswa tersebut akan menyadari bahwa handphone yang hilang tersebut begitu bermakna bagi hidupnya. Sebelumnya mahasiswa itu memang memiliki pengetahuan deskriptif/teoritis tentang handphone, namun pengetahuannya akan eksistensi handphone tersebut justru terungkap ketika mahasiswa itu menggunakannya/beriteraksi langsung dan rusak. Contoh sederhana ini secara gambang menguraikan bahwa pengetahuan dengan present-at-hand (dekriptif/definitif) tidak cukup memadai untuk menyingkap eksistensi benda-benda di sekitar manusia, daripada pengenalan lewat ready-to-hand (interaksi langsung/memakai benda-benda). Beginilah cara Dasein menyingkapkan Ada atau membuat ada menyingkapkan diri (Aletheia) menurut Heidegger. Ada itu tersingkap lewat pengenalan dengan

\footnotetext{
${ }^{76}$ Joko Siswanto, Sistem-Sistem Metafisika barat: dari Aristoteles sampai Derrida / Joko Siswanto (Yogyakarta: Pustaka Pelajar, 1998), 119.

${ }_{77}$ Heidegger and Stambaugh, Being and Time, 47.

${ }^{78}$ Heidegger and Stambaugh, 65.

${ }^{79}$ Adian, Senjakala Metafisika Barat: Dari Hume Hingga Heidegger, 78.
}

19 KACA (Karunia Cahaya Allah): Jurnal Dialogis Ilmu Ushuluddin 
Kritik Metafisika: Studi Komparatif Pemikiran Heidegger ....

interaksi langsung (ontological-existential), bukan lewat pengetahuan deskriptif (ontis).

Konsepsi penyingkapan Ada yang semacam itu secara esensial juga dapat ditemukan dalam filsafat Suhrawardi. Pendiri madzhab filsafat Iluminasi ini mengenalkan terminologi Cahaya dalam konsepsinya tentang penyingkapan Ada. Ia menyatakan bahwa jika terdapat sesuatu yang esksistensinya tidak membutuhkan definisi dan penjelasan, itulah esensi yang tampak atau manifestan. Karena tidak ada sesuatu pun lebih tampak daripada Cahaya, maka tidak ada sesuatu pun yang lebih swamandiri dari definisi selain Cahaya. ${ }^{80}$ Keswamandirian Cahaya ini tidak dimaksudkan untuk meniadakan dunia eksternal, melainkan untuk menjelaskan relasi iluminatif/ kehadiran. Sesuatu yang berada diluar pun bisa menjadi swamandiri ketika ia diketahui melalui proses relasi iluminatif.

Suhrawardi kemudian membagi cahaya menjadi dua, yaitu Cahaya Aksidental (al-Nur al-Arid) dan "Cahaya Abstrak (Non-material)" (al-Nur al-Mujarrad) atau cahaya murni. ${ }^{81}$ Cahaya Abstrak merupakan subtansi yang mengetahui dirinya melalui dirinya sendiri dan tidak memerlukan suatu non-ego untuk mengungkapkan eksistensinya kepada dirinya sendiri. Sementara Cahaya Aksidental adalah atribut yang tidak mempunyai eksistensinya sendiri. Ia merupakan suatu refleksi jauh Cahaya Abstrak yang disebabkan oleh jaraknya, sehingga telah kehilangan intensitasnya atau ciri subtansi induknya. ${ }^{82}$

Lantas di manakah dimensi ontological-existential penyingkapan Ada dalam filsafat Suhrawardi? Secara kasat mata, memang konsepsi Cahayacahaya Suhrawardi tersebut terkesan belum merepresentasikan pengetahuan praksis seperti yang diterapkan Heidegger. Akan tetapi, sebenarnya Suhrawardi masih memberikan penjelasan lajutan terhadapan konsep Cahaya-cahayanya, terutama Cahaya Abstrak. Berikut perincian Suhrawardi akan konsep Cahayanya:

Esensi yang dirinya otonom dan mengenal dirinya, tidak mengenali dirinya dengan representasi dirinya yang tampak oleh dirinya, karena jika pengenalan ini memakai representasi semacam ini, padahal ilustrasi dari "keakuan" (anaiyyah) berbeda dengan representasi tersebut-dalam kaitannya dengan "keakuan" dan representasi sebagai objek yang dikenali-maka pengenalan atas "keakuan" berarti pengenalan atas esensinya sebagai esensi, dan pengenalan dirinya berarti pengenalan atas selain dirinya; dan hal

\footnotetext{
${ }^{80}$ Suhrawardi, Hikmah Al-Isyraq: Teosofi Cahaya Dan Metafisika Hudhuri, 103.

${ }^{81}$ Suhrawardi, 104.

${ }^{82}$ Iqbal, Metafisika Persia: Suatu Sumbangan Untuk Sejarah Filsafat Islam, 100-101.
} 
ini mustahil. Berbeda halnya dengaan objek-objek eksternal, karen representasi dan inti esensi pada objek-objek tersebut memang merupakan esensi itu sendiri. Dan jika ia mengenal melalui representasi (dirinya), ia tidak mengenal dirinya secara sesungguhnya, karena andaikan ia mengetahui bahwa hal itu hanya gambaran dirinya, ia akan mengenali dirinya tanpa gambaran tersebut. Bagaimanapun, tidak terbayangkan bahwa sesuatu mengenali dirinya dengan objek eksternal di luar dirinya, karena hal itu hanyalah sifat baginya. Jika dinyatakan bahwa setiap sifat eksternal-baik berupa pengetahuan atau yang lainnya-ditujukan untuk dirinya, maka ia harus mengenali dirinya sebelum mengenali seluruh sifat aksidental dan sejenisnya. Jadi, ia tidak mungkin mengenali dirinya dengan sifat-sifat eksternal. ${ }^{83}$

Pada pasal perincian cahaya tersebut Suhrawardi membedakan antara term "keakuan" dan "kediaan". Perlu digarisbawahi klasifikasi Suhrawardi tentang "keakuan" dan "kediaan" di sini jangan dimaknai secara denotatif, sehingga memunculkan kesan bahwa "kediaan" merupakan objek eksternal. Klasifikasi tersebut sebenarnya merupakan kelanjutan dari penjelasan Suhrawardi tentang esensi yang swamandiri dan tidak swamandiri yang di sana "keakuan" disamakan dengan esensi yang swamandiri dan "kediaan" sebagai esensi yang tidak swamandiri. Hal ini tidak lain karena "aku" juga dapat dipahami sebagai pengetahuan "kediaan" ketika ia diketahui melalui representasi atau definisi.

Atas dasar argumen tersebut, maka "keakuan" dalam konsepsi Suhrawardi harus dipahami sebagai kesadaran dengan relasi iluminatif (praksis/ontological-existential), sementara "kediaan" merupakan kesadaran dengan deskripsi (intelektual/ontis). Kesadaran dengan ralasi iluminatif inilah yang dimaksud dengan penyingkapan Ada yang terjadi dalam Cahaya. Ketersingkapan Ada dalam Cahaya yang dikonsepsikan Suhrawardi ini secara esensial, tentu tidak jauh berbeda dengan konsep ketersingkapan Ada dalam Dasein. Seperti Heidegger, Suhrawardi juga menjadikan relasi praksis, ontological-existential, sebagai ciri intrinsik penyingkapan Ada.

Dengan demikian, dapat disimpulkan bahwa jauh sebelum Heidegger mengguncang tradisi metafisika Barat dengan kritik kelupaan Ada sebenarnya telah ada filosof lain yang juga berpendapat serupa. Kehadiran sosok Suhrawardi dengan konsep metafisika hudhuri-nya, secara subtantif telah mengisyaratkan proyek kritik metafisika, penghancuran era

${ }^{83}$ Suhrawardi, Hikmah Al-Isyraq: Teosofi Cahaya Dan Metafisika Hudhuri, 107-8. 
kelupaan Ada. Namun, perlu dicatat bahwa ungkapan penulis ini jangan lantas dipahami sebagai upaya pengagungan atau untuk merendahkan tradisi filsafat tertentu. Ungkapan tersebut juga bukan jangan dipahamai sekedar sebagai upaya penulis bernostalgia pada masa keberhasilan filsafat Islam di masa lampau. Melampaui itu, ungkapan tersebut tidak lain, adalah upaya penulis untuk mengafirmasi bahwa ada kemungkinan esistensi solusi yang sama bagi problematika-problematika yang terjadi di dalam dua peradaban yang berbeda. Kesamaan-kesamaan motif pada filsafat Heidegger dan Suhrawardi secara ekspilisit menunjukkan bahwa terdapat realitas-realitas filosofis universal yang memungkinkan pemikir-pemikir dari peradaban yang berbeda berafiliasi dan sepakat dengannya.

\section{Kesimpulan}

Uraian-uraian pada bab-bab sebelumnya menyingkapkan beberapa kesimpulan sebagai berikut: pertama, perbedaan antara pemikiran filsafat Heidegger dan Suhrawardi itu ada tiga, yaitu: 1) Pemikiran filsafat Heidegger dibangun lewat fenomenologi, sedangkan pemikiran filsafat Suhrawardi dibagun melalui filsafat peripatetik, tradisi persia kuno, dan tasawwuf. 2) Pemikiran filsafat Heidegger berdimensi kemanusiaan, sementara pemikiran filsafat Suhrawardi berdimensi keilahian/religius. 3) Heidegger mengkategorikan keakuan performatif sebagai bagian dari level kesadaran ontis dan bukan ontologis, sementara Suhrawardi melihat keakuan performatif sebagai kesadaran ontologis. Kedua, persamaan antara pemikiran Heidegger dan Suhrawardi terletak pada gagasan mereka tentang kritik metafisika. Heidegger dan Suhrawardi memiliki pendapat yang selaras dalam mengkonsepsikan Ada dan cara Ada menyingkapkan diri. Keduanya sama-sama bersepakat bahwa Ada itu hanya dapat tersingkap melalui interaksi langsung, ontological-existential dalam bahasa Hidegger dan idlafah ishraqiyah dalam bahasa Suhrawardi.

Terakhir, rekomendasi untuk kajian-kajian selanjutnya. Masih cukup banyak celah untuk menghadirkan beberapa kajian baru yang berpijak pada pemikiran keduanya. Heidegger yang pemikirannya memiliki beberapa persamaan dengan pemikiran sufistik Suhrawardi itu, masih sangat mungkin untuk dikomparasikan dengan pemikiran-pemikiran sufistik lainnya seperti wahdat al-wujud Ibnu Arabi. Demikian juga dengan Suhrawardi, kritik metafisikanya masih sangat mungkin untuk dikomparasikan dengan filsuf-filsuf Barat, seperti Derrida atau yang lainnya. 


\section{Daftar Pustaka}

Adian, Donny Gahral. Martin Heidegger. Jakarta: Teraju, 2003.

- Pengantar fenomenologi. Cet. 1. Depok: Penerbit Koekosan, 2010.

- Senjakala Metafisika Barat: Dari Hume Hingga Heidegger. Jakarta:

Penerbit Koekoesan, 2012.

Al-Fayyadl, Muhammad. Teologi negatif Ibn 'Arabi: kritik metafisika ketuhanan.

Yogyakarta, Indonesia: LKiS Yogyakarta, 2012.

Aminrazavi, Mehdi. "How Ibn Sīnian Is Suhrawardī's Theory of

Knowledge?" Philosophy East and West 53, no. 2 (2003): 203-14.

Aminrazavi, Mehdi, and Ian Richard Netton. Signifikansi Karya Suhrawardi.

Translated by Ribut Wahyudi. Yogyakarta: Pustaka Sufi, 2003.

Arif, Muhammad. "HERMENEUTIKA HEIDEGGER DAN

RELEVANSINYA TERHADAP KAJIAN AL-QUR'AN.”

Jurnal Studi Ilmu-Ilmu Al-Qur'an Dan Hadis 16, no. 1 (March 16,

2015): 85-106. https://doi.org/10.14421/qh.2015.1601-05.

Asrofi, M. Yusron. "Agama Zoroaster." In Agama-Agama Di Dunia.

Yogyakarta: IAIN Sunan Kalijaga Press, 1988.

Bakker, Anton. Antropologi Metafisik. Yogyakarta: Kanisius, 2000.

Bertens, K. Fenomenologi Ekssistensial. Jakarta: Penerbit Universitas Atma Jaya, 2006.

Drajat, Amroeni. Subrawardi: kritik falsafah peripatetik. Yogyakarta: LKiS Yogyakarta, 2005.

Fain, Lucas. "Heidegger's Cartesian Nihilism." The Review of Metaphysics 64, no. 3 (2011): 555-79.

Fathurrahman, Fathurrahman. "Filsafat Iluminasi Suhrawardi Al-Maqtul." TAJDID: Jurnal Pemikiran Keislaman Dan Kemanusiaan 2, no. 2 (October 31, 2018): 439-56.

https://doi.org/10.52266/tadjid.v2i2.173.

Hardiman, F. Budi. Filsafat fragmentaris: deskripsi, kritik, dan dekonstruksi.

Yogyakarta: Penerbit Kanisius, 2007.

- Heidegger dan Mistik Kesehatan: Roman. Jakarta: KPG, 2016.

Hart, Michael H, Ken Budha Kusumandaru, and M. Nurul Islam. 100 tokoh paling berpengarub di dunia, 2016.

Heidegger, Martin, and Joan Stambaugh. Being and Time: A Translation of

Sein Und Zeit. SUNY Series in Contemporary Continental

Philosophy. Albany, NY: State University of New York Press, 1996.

Henryk, Misiak, and Virginia Staudt Sexton. Psikologi fenomenologi, eksistensial dan humanistik: suatu survei bistoris. Bandung: Refika Aditama, 2005.

Husserl, Edmund. Ideas: General Introduction to Pure Phenomenology. Routledge Classics. London; New York: Routledge, 2012.

23 KACA (Karunia Cahaya Allah): Jurnal Dialogis Ilmu Ushuluddin 
Kritik Metafisika: Studi Komparatif Pemikiran Heidegger ....

Iqbal, Muhammad. Metafisika Persia: Suatu Sumbangan Untuk Sejarah Filsafat Islam. Translated by Joebaar Ayoeb. Bandung: Mizan, 1990.

Jones, Emma R. “'The Future of Sexuate Difference: Irigaray, Heidegger, Ontology, and Ethics." L'Esprit Créateur 52, no. 3 (2012): 26-39.

Kaelan. Filsafat bahasa: masalab dan perkembangannya. Yogyakarta, Indonesia: Paradigma Yogyakarta, 2002.

Lemay, Eric, J. Glenn Pitts, and Paul Gordon. Heidegger untuk pemula. Yogyakarta: Kanisius, 2001.

Louchakova-Schwartz, Olga. "A Phenomenological Approach To Illuminationist Philosophy: Suhrawardī's 'Nūr Mujarrad' And Husserl's Reduction." Philosophy East and West 65, no. 4 (2015): 1052-81.

Love, Jeff, and Michael Meng. "The Political Myths of Martin Heidegger." New German Critique, no. 124 (2015): 45-66.

Marsaoly, M. Said. "Mulla Shadra dan Ilmu Hudhuri." Jurnal Mulla Shadra 1 , no. 1 (2010).

Mcdaniel, Kris. "Heidegger's Metaphysics of Material Beings." Philosophy and Phenomenological Research 87, no. 2 (2013): 332-57.

Misbah Yazdi, Muhammad Taqi. Buku Daras Filsafat Islam. Translated by Musa Kazhim and Saleh Bagir, 2003.

Mousavian, Seyed N. "Suhrawardi on Innateness: A Reply to John Walbridge." Philosopby East and West 64, no. 2 (2014): 486-501.

Nasr, Seyyed Hossein. Tiga Madð̧ab Utama Filsafat Islam. Translated by Ach. Maimun Syamsuddin. Yogyakarta: IRCiSoD, 2006.

Nasution, Harun. Falsafat dan mistisisme dalam Islam falsafat Islam - mistisisme Islam - tasawuf. Jakarta: Bulan Bintang, 2010.

Piliang, Yasraf Amir. Post-Realitas: Realitas Kebudayaan dalam Era PostMetafisika. Yogyakarta: Jalasutra, 2018.

Razavi, Mehdi Amin. Subrawardi and the School of Illumination. Curzon Sufi Series. Richmond, Surrey: Curzon Press, 1997.

Sabri, Muhammad. Lonceng Kematian Mistisme Agama. Yogyakarta: Resist Book, 2009.

Siswanto, Joko. Sistem-Sistem Metafisika barat: dari Aristoteles sampai Derrida / Joko Siswanto. Yogyakarta: Pustaka Pelajar, 1998.

Soleh, A. Khudori. "Filsafat Isyraqi Suhrawardi." ESENSI A: Jurnal IlmuIlmu Ushuluddin 12, no. 1 (January 22, 2011): 1-19. https://doi.org/10.14421/esensia.v12i1.699.

Suhrawardi. Hikmah Al-Ishraq: Teosofi Cahaya Dan Metafisika Hudhuri. Translated by Muhammad al-Fayyadl. Islamika, 2003.

Vogel, Lawrence. "Hans Jonas's Diagnosis of Nihilism: The Case of Heidegger." International Journal of Philosophical Studies 3, no. 1 
Muhammad Arif

(March 1995): 55-72.

https://doi.org/10.1080/09672559508570803.

Walbridge, John. “A Response to Seyed N. Mousavian, 'Did Suhrawardi Believe in Innate Ideas as A Priori Concepts? A Note." Philosophy East and West 64, no. 2 (2014): 481-86.

Yazdi, Mehdi Ha'iri. Menghadirkan Cahaya Tuhan: Epistemiologi Iluminasionis Dalam Filsafat Islam. Indonesia: Mizan, 2003.

Ziai, Hossein. Sang Pencerah Dari Timur: Subrawardi Dan Filsafat Iluminasi.

Translated by Muhammad Afif. Jakarta: Sadra Press, 2012.

25 KACA (Karunia Cahaya Allah): Jurnal Dialogis Ilmu Ushuluddin 